\title{
TANGGUNG JAWAB ATAS KETERLAMBATAN, KERUSAKAN ATAU KEHILANGAN PENGIRIMAN BARANG DI PT. PANDU LOGISTICS
}

\author{
Tira Hana Kristina, Fitika Andraini \\ Fakultas Hukum, Universitas Stikubank (UNISBANK) Semarang \\ E-mail :tira_hana@yahoo.com, fitika@edu.unisbank.ac.id
}

\begin{abstract}
ABSTRAK
Pengangkutan barang dan penumpang di Indonesia meliputi darat, laut, dan udara. Dengan adanya barang-barang dan penumpang yang memerlukan angkutan, maka banyak pengusaha-pengusaha ataupun perusahaan-perusahaan jasa angkutan di ketiga jalur transportasi tersebut. PT. Pandu Logistics merupakan perusahaan yang bergerak dalam bidang jasa pengangkutan barang yang berbadan hukum mengacu pada Layanan Pos Komersial yang tertuang dalam pasal 18 ayat (1) Undang-undang Nomor 38 Tahun 2009 tentang Pos. Selama proses pengiriman barang kadang tidak selalu berjalan dengan lancar, misalnya kemungkinan terjadinya bencana, baik yang berasal dari alam, perbuatan manusia maupun dari sifat barang itu sendiri.

Dalam penulisan hukum ini, metode pendekatanya dilakukan dengan metode yuridis sosiologis dengan spesifikasi deskriptif analitis dan analisanya dilakukan secara kualitatif.

Hasil dari penelitian ini menunjukan bahwa perjanjian baku dalam perjanjian pengangkutan ditentukan secara sepihak yaitu oleh pihak pengangkut sehingga kedudukan para pihaknya tidak seimbang dan tidak ada kebebasan pengirim untuk nenentukan isi perjanjian. Faktor-faktor yang yang menyebabkan terjadinya keterlamabatan, kerusakan atau Kehilangan barang di PT. Pandu Logistics disebabkan 2 faktor, yang pertama faktor internal yang merupakan faktor dari PT. Pandu Logistics itu sendiri dan yang kedua adalah faktor eksternal seperti keadaan alam dan kecelakaan yang tidak mungkin dapat diduga dalam pelaksanaan pengangkutan barang. Tanggung jawab PT. Pandu Logistics Semarang terhadap barang yang hilang atau rusak yaitu dengan cara mengganti kerugian sebesar $10 \mathrm{kali}$ biaya pengiriman atau maksimal Rp. 1.000.000,- (satu juta rupiah), kecuali jika PT. Pandu Logistics Semarang dapat membuktikan secara benar dan jelas bahwa kesalahan tersebut bukan kesalahan dari PT. Pandu Logistics Semarang, melainkan akibat kelalaian dan kesalahan dari pihak pengirim barang atau karena terdapat keadaan memaksa yang mengakibatkan barang muatan tersebut tidak sampai di tangan pihak penerima barang, hal inilah yang membebaskan PT. Pandu Logistics Semarang dari tuntutan yang diajukan oleh pihak pengirim barang. Hal ini sesuai dengan pasal 10 ayat (2) huruf i Peraturan Pemerintah Nomor 15 Tahun 2013 tentang Pelaksanaan Undang-Undang Nomor 38 Tahun 2009 tentang Pos
\end{abstract}

\section{Kata Kunci : Perjanjian Baku, Faktor-Faktor, Tanggung Jawab, Pengiriman Barang}




\begin{abstract}
Freight of goods and passengers in Indonesia With the availability of goods and transportation needed by transportation, there are many entrepreneurs or transportation service companies in the three transportation routes. PT. Pandu Logistik is a company engaged in the transportation of goods which is a legal entity in the Commercial Postal Service as stipulated in article 18 paragraph (1) of Law Number 38 of 2009 concerning Postal. During the process of shipping goods sometimes it does not need to be done with problems, for example regarding expenditures, both originating from nature, human actions or from the nature of the goods themselves.

In answering this law, the approach method is carried out using the sociological juridical method with descriptive analytical specifications and the analysis is done qualitatively.

The results of this study indicate that the standard agreement in the transportation agreement determined by the carrier according to the position of the parties is not balanced and there is no freedom of transfer to determine the contents of the agreement. Factors that cause ownership change, damage or loss of goods in PT. Pandu Logistics is 2 factors, the first factor which is a factor of PT. Pandu Logistik itself and the second is external factors such as circumstances and accidents that cannot be done in the transportation of goods. The responsibility of PT. Pandu Logistics Semarang for lost or damaged goods that is by way of compensation of 10 times the shipping fee or a maximum of Rp. 1,000,000 (one million rupiah), except if PT. Pandu Logistik Semarang can prove right and wrong that PT. Pandu Logistik Semarang, apart from the negligence and mistakes of the sender of the goods or because there is something about the cargo that does not reach the recipient of the goods, this is what frees PT. Pandu Logistik from Semarang sent by the goods sender. This is in accordance with article 10 paragraph (2) letter i Government Regulation Number 15 Year 2013 concerning Regulation Number 38 Year 2009 concerning Postal
\end{abstract}

Keywords: Standard Agreement, Factors, Responsibility, Delivery of Goods 


\section{Pendahuluan}

Pengangkutan merupakan serangkaian perbuatan mulai dari pemuatan ke dalam alat pengangkut, kemudian dibawa menuju ke tempat yang telah ditentukan, dan pembongkaran atau penurunan di tempat tujuan. Pengangkutan sebagai perjanjian, pada umumnya bersifat lisan (tidak tertulis) tetapi selalu didukung oleh dokumen angkutan yang membuktikan bahwa perjanjian sudah terjadi. Pengangkutan sebagai proses merupakan sistem hukum yang mempunyai unsur-unsur sistem, yaitu :

(1) Subjek (pelaku) hukum pengangkutan, yaitu pihak-pihak dalam perjanjian dan pihak yang berkepentingan dalam pengangkutan.

(2) Status pelaku hukum pengangkutan, khususnya pengangkut selalu berstatus perusahaan badan hukum atau bukan badan hukum.

(3) Objek hukum pengangkutan, yaitu segala sesuatu yang digunakan untuk mencapai tujuan hukum pengangkutan.

(4) Peristiwa hukum pengangkutan, yaitu proses penyelenggaraan pengangkutan.

(5) Hubungan hukum pengangkutan, yaitu hubungan kewajiban dan hak antara pihak-pihak dan mereka yang berkepentingan dengan pengangkutan.

Dengan adanya pelaksanaan pengangkutan ini secara langsung juga akan berpengaruh terhadap perlindungan hukum bagi pihak pengirim barang yang menggunakan sarana angkutan tersebut karena bila penyelenggaraan pengangkutan tidak selamat akan terjadi dua hal, yaitu barangnya sampai di tempat tujuan tidak ada (musnah) atau ada, tetapi rusak, sebagian atau seluruhnya. Barang yang tidak ada atau mungkin disebabkan karena terbakar, tenggelam, dicuri orang, dibuang dilaut, dan lain-lain. Barang rusak sebagian atau seluruhnya, meskipun barangnya ada, tetapi tidak dapat dipergunakan sebagaimana mestinya. Kalau barang tidak ada atau ada tetapi rusak, menjadi tanggung jawab pengangkut, artinya pengangkut harus membayar ganti kerugian terhadap barang yang musnah atau rusak tersebut.

Dalam perjanjian pengangkut terkait dua pihak, yaitu pengangkut dan pengirim barang. Jika tercapai kesepakatan diantara para pihak, maka pada saat itu lahirlah perjanjian pengangkutan. Apabila pengangkut telah melaksanakan kewajibanya menyelenggarakan pengangkutan barang atau penumpang, pengangkut telah terikat pada konsekuensikonsekuensi yang harus dipikul oleh pengangkut barang atau tanggung jawab terhadap penumpang dan barang muatan yang diangkutnya. Dari kewajiban itu timbul tanggung jawab pengangkut, maka segala sesuatu yang mengganggu keselamatan penumpang atau barang menjadi tanggung jawab pengangkut. Dengan demikian, berarti pengangkut berkewajiban menanggung segala kerugian yang diderita oleh penumpang atau barang yang diangkutnya tersebut.

Adapun kewajiban lain dari pengangkut adalah menyelenggarakan 
pengangkutan penumpang atau barang dengan selamat. Sedangkan pihak pengirim mempunyai kewajiban membayar uang pengangkutan atau biaya pengiriman, sehingga dalam penyelenggaraan pengiriman atau paket barang ini, jika pengirim akan mengirimkan barangnya lewat jasa perusahaan pengangkutan, selanjutnya setelah barang diserahkan, pihak perusahaan pengangkutan akan menerima barang atau paket tersebut. Maka sejak itu, tanggung jawab mengenai barang atau paket tersebut ada pada perusahaan pengangkutan.

PT. Pandu Logistics merupakan perusahaan yang bergerak dalam bidang jasa pengangkutan barang yang berbadan hukum mengacu pada Layanan Pos Komersial yang tertuang dalam pasal 18 ayat (1) Undangundang Nomor 38 Tahun 2009 tentang Pos. Sebagai perusahaan yang bergerak dalam bidang jasa pengangkutan barang, PT. Pandu Logistics telah menerima titipan suatu barang dari orang atau perusahaan yaitu pihak pengirim, PT. Pandu Logistics selanjutnya bertanggung jawab untuk menyelenggarakan pengangkutan atau selanjutnya bertanggung jawab untuk dikirim ke tempat tujuan yang dituju dengan selamat. Artinya bahwa pihak pengangkut, yaitu PT. Pandu Logistics bertanggung jawab atas keselamatan barang dan keamanan barang yang harus diangkutnya, mulai saat diterimanya hingga saat diserahkannya barang tersebut ke tangan penerima. Serta apabila dalam pengangkutan barang tersebut berjalan tidak selamat, misalnya barang tersebut mengalami kerugian akibat kehilangan, kerusakan, atau keterlambatan dalam pengirimanya, maka hal ini juga menjadi tanggung jawab pengangkut. Namun mengenai tanggung jawab tersebut ada pembatasannya. Pengangkut bertanggung jawab untuk memberikan ganti rugi pada pengirim apabila kerugian akibat kehilangan, kerusakan, atau keterlambatan barang yang dikirim tersebut karena kelalaiannya, kecuali apabila kerugian itu timbul karena salah satu sebab sebagai berikut :

(1) Keadaan yang memaksa (overmatch)

(2) Cacat barang itu sendiri

(3) Kesalahan atau kelalaian pengirim

(4) Keterlambatan datangnya karena keadaan memaksa (diatur dalam ketentuan pasal 91 dan pasal 92 Kitab Undang-undang Hukum Dagang)

Berdasarkan uraian dari latar belakang yang telah dikemukakan diatas, maka perumusan masalah yang timbul dalam penelitian adalah sebagai berikut :

1. Bagaimana perjanjian pengangkutan barang di PT. Pandu Logistics?

2. Faktor apa saja yang menyebabkan terjadinya keterlambatan, kerusakan, atau kehilangan barang di PT. Pandu Logistics?

3. Bagaimana tanggung jawab hukum PT. Pandu Logistics apabila terjadi keterlambatan, kerusakan, ataupun kehilangan barang? 
Metode Penelitian

Penelitian tentang "Tanggung Jawab Atas Keterlambatan, Kerusakan Atau Kehilangan Pengiriman Barang Di PT. Pandu Logistics" ini merupakan suatu penelitian hukum dengan mempergunakan cara pendekatan yuridis sosiologis.

Fokus penelitian menggunakan penelitian yang diskriptif. Penelitian diskriptif maksudnya penelitian yang bertujuan untuk menggambarkan secara sistematis, faktual dan akurat terhadap obyek yang menjadi pokok permasalahan.

Data yang dikumpulkan adalah data yang berhubungan dengan peraturan perundang-undangan yang berlaku yakni Undang-Undang Nomor 22 Tahun 2009 tentang Lalu Lintas Angkutan Jalan, Undang-Undang Nomor 38 Tahun 2009 Tentang Pos serta akan ditinjau pula dengan teoriteori di dalam hukum pengangkutan serta pengumpulan data dalam penelitian ini ditunjang dengan wawancara pengusaha penyedia jasa angkutan barang yaitu pihak dari PT. Pandu Logistics.

\section{Pembahasan}

\section{Perjanjian pengangkutan barang di PT. Pandu Logistics}

Setiap kali ada pengiriman barang melalui PT. Pandu Logistics, pihak pengirim harus mengisi AWB (Air Waybill), yaitu form pengisian pengiriman barang. Air Waybill yang selanjutnya akan disebut AWB merupakan dokumen penting yang nantinya akan menjadi bukti pengiriman. Didalam AWB terdapat perjanjian konosemen yang diadalamnya terdapat nama, alamat yang lengkap, jelas, benar dan terbaca, meliputi Kecamatan, Kabupaten / Kota, serta Provinsi agar barang atau dokumen yang akan dikirim bisa sampai ke tempat yang dituju. AWB juga memuat isi kiriman, nilai kiriman, intruksi khusus, berat asli, berat volume, pcs, dimensi. AWB sendiri memiliki beberapa fungsi yang cukup penting, yaitu :

a. Berfungsi sebagai bukti pengiriman (untuk pengirim)

b. Berfungsi sebagai bukti pembayaran/kwitansi

c. Berfungsi sebagai arsip/file

d. Berfungsi sebagai bukti serah terima (untuk penerima)

Saat pengirim menyerahkan barang atau dokumen untuk dikirim melalui PT. Pandu Logistics, para pengirim dianggap telah menerima dan menyetujui perjanjian dan persyaratan dan ketentuan standar yang ditetapkan PT. Pandu Logistics. Berikut tata cara pengiriman barang di PT. Pandu Logistics : Pengirim mengantar barang ke pengangkut/ PT. Pandu Logistics, PT. Pandu Logistics menerima barang dari pengirim, Pengirim dan Pengangkut menyepakati perjanjian, yang tertera pada AWB, Barang yang akan diangkut menjadi tanggung jawab sepenuhnya pengangkut/ PT. Pandu Logistics, Pengangkut mengirim paket barang di tempat tujuan sesuai alamat yang tertera. 
Perjanjian atau perikatan adalah suatu perbuatan yang mempunyai hubungan hukum antara dua orang atau lebih, pihak yang satu memberikan sesuatu hak dan pihak lainnya berkewajiban melaksanakan suatu prestasi.

Perjanjian yang dibuat dalam pengangkutan di PT. Pandu Logistics menggunakan perjanjian baku sepihak dimana isi dari perjanjian itu ditentukan oleh pihak yang kuat kedudukannya dan dalam hal ini adalah pengangkut atau PT. Pandu Logistics, sementara pihak yang lain yaitu pengirim tidak diikutkan dalam pembuatannya. Jadi kedudukan pengangkut lebih dominan daripada pengirim, karena pengangkut mempunyai wewenang yang lebih untuk menentukan segala sesuatu yang berhubungan dengan perjanjian pengangkutan dimana bentuk dan isi perjanjian telah ditentukan oleh pihak pengangkut secara sepihak tanpa mengikut sertakan pihak pengirim.

Selain itu perjanjian pengangkutan menganut asas koordinasi, yaitu pihak-pihak dalam pengangkutan memiliki kedudukan yang sama tinggi atau sejajar. Sekalipun pengangkut menyediakan jasa dan melaksanakan permintaan dari penumpang maupun pengirim barang, pengangkut bukanlah bawahan atau suruhan dari penumpang/pengirim barang, karena pengangkutan merupakan perjanjian pemberian kuasa.
Perjanjian yang sah artinya perjanjian yang memenuhi syaratsyarat yang telah ditentukan oleh undang-undang, sehingga diakui oleh hukum. Suatu perjanjian pengiriman barang dapat dikatakan sah apabila telah memenuhi syarat-syarat perjanjian yang telah ditentukan dari beberapa ketentuan perundangundangan yang telah dibuat secara khusus untuk mengatur penyelenggaraan pengiriman barang maupun syarat-syarat perjanjian yang telah ditentukan oleh perusahaan penyelengaraan jasa pengiriman itu sendiri. Menurut pasal 1320 KUHPerdata, perjanjian yang sah apabila memenuhi persyaratan yaitu kesepakatan para pihak yang mengikatkan diri antara pengirim dan pengangkut, kecakapan untuk membuat perjanjian, hal tertentu yakni barang-barang yang menjadi obyek perjanjian dalam pengangkutan, sebab yang diperbolehkan dalam perjanjian tidak boleh bertentangan dengan undang-undang.

PT. Pandu Logistics dalam hal ini bertindak sebagai badan usaha didasarkan pada Layanan Pos Komersial yang mengacu pada Pasal 18 ayat 1 UndangUndang Nomor 38 Tahun 2009 tentang Pos. Perjanjian pengangkutan di PT. Pandu Logistics menganut asas konsensual dimana perjanjian pengangkutan terjadi jika ada kata sepakat antara pengirim dan pengangkut. 
2. Faktor yang menyebabkan terjadinya keterlambatan, kerusakan, atau kehilangan barang di PT. Pandu Logistics

\begin{tabular}{lrrr}
\multicolumn{1}{c}{ Faktor yang } & $\begin{array}{r}\text { menyebabkan } \\
\text { keterlambatan, }\end{array}$ \\
terjadinya & \multicolumn{3}{c}{ ketand } \\
kerusakan ataupun & kehilangan \\
barang dalam & proses \\
pengangkutan di PT. & Pandu
\end{tabular} Logistics adalah sebagai berikut:

a. Berupa faktor alam seperti cuaca yang buruk atau hujan. Dalam keadaan hujan maka jarak pandang dari pengemudi sangat terbatas dan sangat rawan terjadi kecelakaan, tidak jarang proses pengangkutan itu dihentikan dengan tujuan untuk menjaga keselamatan barang.

b. Berupa faktor kecelakaan lalu lintas, hal ini bisa terjadi karena kondisi dari kelalaian pengemudi itu sendiri dan dari pengemudi lain.

c. Berupa faktor kurang siapnya kondisi armada yang digunakan sebagai alat pengangkut, seperti ban atau rem yang sudah aus atau tipis, lampu depan atau belakang yang mati atau tidak menyala, yang dapat menyebabkan terjadinya kecelakaan sehingga menimbulkan keterlambatan ataupun kerusakan barang paket.

d. Berupa faktor kurang bagus atau sempurnanya pembungkusan barang yang berakibat pada kerusakan barang. e. Berupa faktor sumber daya manusia, seperti kurang profesionalnya atau kurang disiplinnya karyawan atau pengemudi atau supervisor (pengawas) dalam pengiriman atau pengangkutan barang. Upaya yang dilakukan PT. Pandu Logistics untuk mengatasi kendala dalam proses pengangkutan

a. Terhadap kendala berupa faktor alam, maka yang dilakukan adalah kegiatan atau proses pengangkutan dihentikan sejenak sehingga dapat mencegah terjadinya kecelakaan yang dapat menimbulkan keterlambatan atau kerusakan barang.

b. Terhadap kendala kurang siapnya armada maka yang dilakukan adalah dengan melakukan monitor secara terpadu yaitu pengecekan kondisi dari armada (truk, motor), sehingga kondisi armada tetap terjaga.

c. Terhadap kendala berupa sumber daya manusia maka pihak perusahaan lebih sering melakukan pembinaan dalam peningkatan profesionalitas kerja. Adanya peraturan kerja pengemudi juga sebagai upaya dalam ranga peningkatan sumber daya manusia. 
3. Tanggung Jawab PT. Pandu Logistics apabila terjadi keterlambatan, kerusakan, ataupun kehilangan barang

Berkaitan dengan tanggung jawab PT. Pandu Logistics selaku pengangkut bertanggung jawab atas barang yang diangkutnya mulai dari pengirim datang ke pengangkut sampai dengan barang yang akan diangkut sampai di tempat si penerima barang.

Apabila terjadi keterlambatan pengiriman paket oleh PT. Pandu Logistics, maka perusahaan akan melakukan peninjauan terlebih dahulu, apa yang menyebabkan terjadinya keterlambatan, apa karena force majure atau murni karena human error, apabila memang terbukti karena kesalahan dari si pengemudi atau kurir maka PT. Pandu Logistics akan menggangti kerugian berupa maksimal 10 kali dari biaya pengiriman barang atau dokumen yang hilang saja dan maksimal Rp. 1.000.000,- (satu juta rupiah) dengan didahului pengajuan keringanan klaim atas keterlambatan atau kehilangan tersebut, hal ini sesuai dengan surat order pengangkutan yang menjadi dasar dari perjanjian antara si pengirim dengan pengangkut dalam hal ini PT. Pandu Logistics

Adapun prosedur pengaduan/klaim atas kehilangan atau kerusakan pada barang pengiriman yang ditetapkan oleh PT. Pandu Logistics yaitu sebagai berikut : a. Pengaduan/klaim harus diajukan 7 (tujuh) hari terhitung sejak diterimanya barang tersebut beserta dokumen-dokumen yang terkait.

b. Pengirim datang langsung ke kantor cabang PT. Pandu Logistics dimana pengirim menyerahkan barangnya pertama kali untuk dikirimkan untuk memberitahu adanya keluhan/pengaduan.

c. Pengirim membawa dokumen angkutan AWB sebagai bukti terjadinya perjanjian pengangkutan dengan PT. Pandu Logistics.

d. Pengirim membawa fotocopy identitas diri (KTP) sebagai bukti agar dapat diketahui bahwa dokumen kiriman adalah benar-benar milik pengirim. Apabila pengirim merupakan suatu badan usaha, maka perlu dibubuhi cap resmi dari perusahaan.

e. Pengirim membawa surat klaim atau aduan berupa kronologis kejadian bisa juga menceritakan secara lisan, seperti kapan pengirim memberikan barang pada cabang PT. Pandu Logistics, apa jenis barang, dan lainlain.

f. Pengirim membawa invoice asli dari barang kiriman yang hilang tersebut.

g. Setelah semua dokumen lengkap, pembayaran atas klaim akan dilakukan dalam kurun waktu 3 (tiga) hari 
kerja setelah investigasi atau pengecekan selesai dilakukan. Apabila dalam proses pengangkutannya terjadi hal-hal diluar dugaan atau di luar kendali dari pihak pengirim yang ditimbulkan selama proses penyelenggaraan pengiriman tersebut, maka PT. Pandu Logistics terikat untuk bertanggung jawab atas segala kerugian dari kerugian yang timbul dalam proses penyelenggaraan pengiriman yang dilakukannya, sehingga jika pihak PT. Pandu Logistics dapat membuktikan bahwa ia tidak bersalah maka ia dapat dibebaskan dari kewajiban untuk membayar ganti kerugian yang dibebankan kepadanya, yang dimaksud tidak bersalah adalah karena hal-hal yang terjadi di luar kemampuannya, seperti karena adanya bencana alam atau dikarenakan sifat dari barangbarang yang dikirimnya.

Dalam pasal 1239

KUHPerdata yang mengatur bahwa tiap-tiap perikatan untuk berbuat sesuatu, atau untuk tidak berbuat sesuatu, apabila si berutang tidak memenuhi kewajibannya, mendapatkan penyelesaiannya dalam kewajiban memberikan penggantian biaya, rugi, dan bunga. Jadi, jika dalam pelaksanaan pengangkutan, pengangkut tidak melakukan kewajibannya maka pengangkut harus membayar ganti rugi. Pengangkut dibebaskan dari kewajiban membayar ganti rugi apabila kerugian yang terjadi bukan karena perbuatan wanprestasi (kesalahan) pengangkut melainkan kerugian tersebut terjadi karena adanya keadaan memaksa (overmacht atau force majeur) yaitu suatu keadaan yang disebabkan oleh hal-hal yang sama sekali tidak dapat diduga dan pihak yang bersangkutan tidak dapat berbuat apa-apa terhadap keadaan atau peristiwa yang timbul di luar dugaan tadi.

Sedangkan dalam pasal 1243 KUHPerdata tanggung jawab dalam penggantian biaya, kerugian karena tak dipenuhinya suatu perikatan mulai diwajibkan, bila pengirim, walaupun telah dinyatakan Ialai, tetap Ialai untuk memenuhi perikatan itu, atau jika sesuatu yang harus diberikan atau dilakukannya hanya dapat diberikan atau dilakukannya dalam waktu yang melampaui waktu yang telah ditentukan.

Keadaan memaksa merupakan suatu alasan bagi pihak yang bersangkutan untuk dibebaskan dari kewajiban membayar ganti rugi sesuai dengan aturan pasal 1245 KUHPerdata yang mengatur bahwa tidaklah biaya, rugi, dan bunga harus digantinya, apabila karena keadaan memaksa atau karena suatu kejadian yang tak disengaja, si berhutang berhalangan memberikan atau berbuat sesuatu yang diwajibkan, atau karena hal-hal yang sama 
telah melakukan perbuatan terlarang.

Didalam undang-undang Nomor 8 Tahun 1999 tentang Perlindungan Konsumen juga mengatur mengenai tanggung jawab pelaku usaha dalam pasal 19, pelaku usaha yang dimaksud disini adalah pengangkut atau PT. Pandu Logistics, dalam ayat (1) dinyatakan bahwa pelaku usaha bertanggung jawab memberikan ganti kerugian atas kerusakan, pencemaran dan/atau kerugian konsumen akibat mengkonsumsi barang dan/atau jasa yang dihasilkan atau diperdagangkan. Berdasarkan ketentuan ini, PT. Pandu Logistics bertanggung jawab memberikan ganti kerugian kepada pengirim yang mengalami kerugian. Pasal 19 ayat (2) UUPK menyatakan bahwa ganti rugi dapat berupa pengembalian uang atau penggantian barang dan/atau jasa yang sejenis atau setara nilainya dan/atau pemberian santunan yang sesuai dengan ketentuan peraturan perundangundangan yang berlaku. Dalam hal ini PT. Pandu Logistics memberikan ganti rugi berupa 10 kali ongkos kirim atau maksimal Rp. 1.000.000,- (satu juta rupiah) jika terbukti ada unsur kesalahan atau kelalaian. Pasal 28 UUPK menyebutkan bahwa pembuktian terhadap ada tidaknya unsur kesalahan dalam gugatan ganti rugi merupakan beban dan tanggung jawab pelaku usaha atau PT. Pandu Logistics.
Adapun upaya yang dilakukan PT. Pandu Logistics jika pengirim meminta ganti rugi lebih atas kerugian yang dideritanya yaitu dengan musyawarah. Proses ini diawali dengan pengajuan tuntutan ganti rugi disertai bukti yang dilakukan pengirim kepada PT. Pandu Logistics, kemudian PT. Pandu Logistics akan menawarkan penyelesaian masalah melalui musyawarah kepada pengirim. Jika pengirim pengirim sepakat untuk menyelesaikan permasalahan tersebut melalui musyawarah, maka PT. Pandu Logistics akan memeriksa tuntutan ganti rugi tersebut, yang nantinya jika memang benar terbukti PT. Pandu Logistics yang melakukan kesalahan atau kelalaian dalam penyelenggaraan pengangkutan dokumen, maka PT. Pandu Logistics akan mengajak pihak pengirim untuk mengadakan musyawarah dengan bernegosiasi tentang jumlah ganti rugi yang diberikan. Musyawarah ini dilakukan pihak PT. Pandu Logistics karena perusahaan menganggap penyelesaian tuntutan ganti rugi dengan jalur musyawarah lebih mudah dan tidak memerlukan waktu yang lama.

Dalam hal barang yang dikirimkan hilang, maka admin PT. Pandu Logistics pengirim akan melakukan pelacakan (Tracking), agar diketahui bahwa barang tersebut benar-benar hilang atau terjadi salah kirim pada alamat tertentu. Apabila barang 
yang dikirimkan terbukti hilang atau rusak maka ganti kerugian untuk barang pengiriman maka ganti kerugian maksimal adalah 10 kali ongkos kirim atau setinggitingginya sebesar Rp. 1.000.000,(satu juta rupiah). Khusus untuk kiriman dokumen, nilai penggantian maksimal adalah Rp. 100.000 (seratus ribu rupiah). Hal ini sesuai dengan pasal 10 ayat (2) huruf i Peraturan Pemerintah Nomor 15 Tahun 2013 tentang Pelaksanaan Undang-Undang Nomor 38 Tahun 2009 tentang Pos yang berbunyi, "jaminan pemberian ganti rugi atas keterlambatan, kehilangan, ketidaksesuaian layanan dan kerusakan yang terbukti sebagai akibat kelalaian dan kesalahan Penyelenggara Pos paling tinggi 10 (sepuluh) kali biaya pengiriman, kecuali kiriman yang diasuransikan.”

\section{Simpulan}

Pelaksanaan perjanjian barang di PT. Pandu Logistics Semarang dimulai sejak pihak pengirim datang ke kantor cabang di PT. Pandu Logistics Semarang untuk mengirimkan barangnya, pengirim memberikan informasi yang sesuai dan sebenarbenarnya mengenai barang yang hendak dikirimkan. Pelaksanaan perjanjian baku di PT. Pandu Logistics sudah tertulis dalam surat muatan yang dalam pembuatan klausulanya dibuat oleh salah satu pihak yaitu pihak pengangkut atau PT. Pandu Logistics, apabila pengirim setuju dengan segala syarat dan ketentuan pengiriman yang ada dalam surat muatan maka pihak pengirim diminta untuk mengisi datadata yang tertera di surat muatan pengiriman. Pengangkut akan mengecek barang yang akan dikirimkan sesuai dengan persetujuan kedua belah pihak, setelah barang melalui tahap pengecekan maka akan langsung dikirimkan ke tempat tujuan. Setelah barang sampai di tempat tujuan, pihak pengangkut dalam hal ini PT. Pandu Logistics pada daerah yang dituju akan mengecek dan langsung mengirimkan barangnya ke alamat penerima.

Faktor yang menyebabkan atas terjadinya keterlambatan, kerusakan ataupun pengiriman barang di PT. Pandu Logistics disebabkan oleh 2 faktor, yang pertama faktor internal atau faktor dari PT. Pandu Logistics sendiri, seperti misalnya kerusakan mesin alat pengangkut, pengepakan barang yang akan diangkut, serta kesalahan dalam penulisan kota barang yang akan diangkut. Dan faktor eksternal seperti keadaan alam dan kecelakaan yang tidak mungkin dapat diduga dalam pelaksanaan pengangkutan barang.

Tanggung jawab PT. Pandu Logistics Semarang sebagai pengangkut dimulai sejak barang angkutan diserahkan dalam penguasaan pengangkut di kantor cabang PT. Pandu Logistics Semarang selama proses pengangkutan berlangsung dan sampai saat proses penyerahan kepada pihak penerima. Namun, pihak PT. Pandu Logistics Semarang dapat menolak untuk bertanggung jawab apabila kerugian yang terjadi timbul akibat pengirim 
yang tidak memberitahukan secara jujur isi dari barang yang hendak dikirim, pengirim tidak mengemas barang pengiriman dengan baik dan kurang sempurna dan kesalahan penulisan alamat tujuan oleh pengirim. Jika hal itu terjadi maka kerugian tersebut menjadi tanggung jawab pengirim. Pembayaran biaya ganti kerugian atas barang kiriman yang hilang atau rusak, maksimal adalah 10 (sepuluh) kali ongkos kirim atau setinggi-tingginya sebesar Rp. 1.000.000,- (Satu Juta Rupiah). Hal ini sesuai dengan pasal 10 ayat (2) huruf i Peraturan Pemerintah Nomor 15 Tahun 2013 tentang Pelaksanaan Undang-Undang Nomor 38 Tahun 2009 tentang Pos

\section{Saran}

Dalam perjanjian pengangkutan sebaiknya kedudukan pengangkut setara dengan kedudukan pengirim agar asas kebebasan berkontrak dapat diwujudkan. Walaupun perusahaan angkutan menggunakan perjanjian baku dalam perjanjian pengangkutan, diharapkan perusahaan angkutan tersebut tetap memberikan kesempatan kepada pengirim untuk bisa bernegosiasi mengubah klausula dalam perjanjian tersebut yang sekiranya tidak merugikan pengirim.

Perusahaan PT. Pandu Logistics yang bergerak dalam bidang jasa pengangkutan barang harus lebih memperhatikan kepuasan pelanggan sehingga lebih meningkatkan keamanan, keselamatan dan ketepatam pengangkutan barang. Selain itu perlu adanya peningkatan sumber daya manusia (SDM) yang memadai, yang berkemampuan dalam penyelenggaraan transportasi, baik dalam segi pengelolaan maupun penguasaan teknologi.

Perusahaan angkutan sebaiknya tidak membatasi jumlah pemberian ganti rugi terhadap barang yang mengalami kerugian akibat dari kesalahan pengangkut sebesar 10 kali biaya pengangkutan. Jumlah ganti rugi ini dianggap kurang adil bagi pihak yang menderita kerugian. Seharusnya pemberian ganti rugi melihat juga nilai dari barang yang mengalami kerugian tersebut. Jika barang tersebut mempunyai nilai tinggi maka ganti ruginya pun akan menyesuaikan dengan nilai dari barang tersebut dan tidak hanya dihitung dari berat barang saja. Perusahaan angkutan tidak perlu membatasi tanggung jawabnya karena tanggung jawab pengangkut tidak diatur dalam Undang-Undang. Apabila terjadi kerugian yang menurut Undang-Undang adalah menjadi tanggung jawab pengangkut maka hal tersebut tetap menjadi tanggung jawab pengangkut walaupun pengangkut telah melakukan pembatasan terhadap tanggung jawabnya tersebut.

\section{Daftar Pustaka}

\section{Literatur}

Amad Sudiro, Martono, 2010, Hukum Angkutan Udara, cetakan kesatu, PT. Rajagrafindo Persada, Jakarta.

Budiono, Herlin, 2009, Ajaran Umum Hukum Perjanjian dan Penerapanya di Bidang Kenotariatan, PT. Citra Aditya Bakti, Bandung. 
Hasyim, Farida, 2009, Hukum Dagang, Sinar Grafika, Jakarta.

H.K Martono, Eka Budi Tjahyono, 2011, Transportasi di Perairan berdasarkan Undang-Undang Nomor 17 Tahun 2008, PT. Raja Grafindo Persada, Jakarta.

Moleong, L, 2004, Metodologi Penelitian Hukum, Sinar Grafika, Jakarta.

Muhammad, Abdulkadir, 1991, Hukum Pengangkutan Darat, laut, udara, Cet pertama, PT. Citra Aditya Bakti, Bandung.

Muhammad, Abdulkadir, 1998, Hukum Pengangkutan Niaga, Cet ketiga, PT. Citra Aditya Bakti, Bandung.

Muhammda, Abdulkadir, 2008, Hukum Pengangkutan Niaga, Cet keempat, PT. Citra Aditya Bakti, Bandung.

Purba, Hasim, 2005, Hukum Pengangkutan di Laut, Penerbit Pustaka Bangsa Press, Medan.

Purwosutjipto, H.M.N, 1991, Pengertian Pokok Hukum Dagang Indonesia, Hukum Pengangkutan, Jakarta.

R. Subekti, 1989, Aneka Perjanjian, Cet kedelapan, Citra Aditya Bhakti, Bandung.

R. Subekti, 2010, Hukum Perjanjian, Cetakan XI, PT. Intermasa, Jakarta

Soekanto, Soerjono, 2005, Pengantar Penelitian Hukum, Universitas Indonesia (UI-Press), Jakarta.

Suharnoko, 2004, Hukum Perjanjian, Prenada, Jakarta

Utari, Siti, 1994, Pengangkutan Laut di Indonesia (suatu tinjauan yuridis), Balai Pustaka, Jakarta.
Peraturan Perundang-undangan

Undang-undang Nomor. 23 Tahun 2009 tentang Lalu Lintas dan Angkutan Jalan.

Subekti, R. Dan Tjitrosudjbio, Kitab Undang-undang Hukum Perdata, Jakarta, Penerbit Pradnya Paramita.

Subekti, R. Dan Tjitrosudjbio, Kitab Undang-undang Hukum Dagang, Jakarta, Penerbit Pradnya Paramita.

\section{Website}

Setiawan, Ebta, 2012-2019, Kamus Besar Bahasa Indonesia $(K B B I)$, Internet, Tersedia di : http://kbbi.web.id/pengangkuta n, Diakses pada 5 Februari 2019.

Setiawan, Ebta, 2012-2019, Kamus Besar Bahasa Indonesia (KBBI), Internet, Tersedia di : http://kbbi.web.id/tanggung\%2 0jawab, Diakses pada 5 Februari 2019.

\section{Jurnal}

Fitriana Novitasari Istiharoh, 2018, Studi Tentang Jasa Pengiriman Hewan Melalui Pengangkutan Darat di PT. Herona Express Cabang Surakarta, Privat Law, Vol. 6 No. 1.

Arikha Saputra, 2019, Tindakan Hukum Penggunaan Ponsel Pada Ojek Online Saat Berkendara, Jurnal Komunikasi Hukum (JKH) Universitas Pendidikan Ganesha, Vol. 4 No. 2, hal. 43. 